\title{
RANCANG BANGUN SISTEM INFORMASI REKAM MEDIS BERBASIS KOMPUTER DI RSB KERTAYASA NEGARA
}

\author{
ANASTASIA KADAR SULISTIATI \\ Prodi Perekam dan Informasi Kesehatan, Fakultas Ilmu Kesehatan, Sains dan Teknologi, \\ Universitas Dhyana Pura, Bali \\ lucienneosf@yahoo.com
}

\begin{abstract}
Medical record information system is a system that intend to manage patients data enrolled for treatment until the patient is discharged from the hospital in a given period. Medical record information system designed because it is important to prevent the occurrence of errors in the implementation of registration procedures and data processing. Management of patient data in RSB Kertayasa still manual and not computerized. Along with the development of the RSB Kertayasa which will be the General Hospital, the medical record information system-based computer becomes a vital necessity for the hospital. Therefore, this study aims to design an information system Windows XP-based medical record. Medical record information system design in RSB Kertayasa consists of literature studies, system planning, system analysis, system design, system implementation, testing and reporting.

Medical record information system design in RSB Kertayasa generate patient registration application until the patient is discharged from the hospital. In designing this application, multiple databases need to be designed, forms, patient medical records and reports to support the operation of the application. Designed database is a database of patients and medical record database. Form designed the login form, the main form, patient registration forms, medical records form, and user settings. The resulting report is a report patient medical records and reports.
\end{abstract}

Keywords : Information Systems, Medical Records, Patient.

\begin{abstract}
ABSTRAK
Sistem Informasi rekam medis merupakan sistem yang bertujuan untuk mengelola data pasien yang mendaftar untuk berobat hingga pasien tersebut keluar dari rumah sakit pada suatu periode tertentu. Sistem informasi rekam medis sangatlah penting untuk dirancang karena mencegah terjadinya kesalahan prosedur dalam pelaksanaan pendaftaran dan pengolahan data. Pengelolaan data pasien di RSB Kertayasa masih bersifat manual dan belum terkomputerisasi. Seiring dengan perkembangan RSB Kertayasa yang akan menjadi Rumah Sakit Umum maka sistem informasi rekam medis berbasis komputer menjadi kebutuhan vital bagi rumah sakit. Oleh karena itu penelitian ini bertujuan merancang suatu sistem informasi rekam medis berbasis Windows XP. Dalam perancangan sistem informasi rekam medis di RSB Kertayasa ini terdiri dari studi literatur, perencanaan sistem, analisis sistem, desain sistem, implementasi sistem, pengujian dan penulisan laporan.

Perancangan sistem informasi rekam medis di RSB Kertayasa menghasilkan sebuah aplikasi pendaftaran pasien hingga pasien tersebut keluar dari rumah sakit. Dalam merancang aplikasi ini maka perlu dirancang beberapa database, form, data rekam medis pasien dan laporan untuk mendukung pengoperasian aplikasi. Database yang dirancang yaitu database pasien dan database rekam medis. Form yang dirancang yaitu form login, form utama, form pendaftaran pasien, form rekam medis, dan pengaturan user. Laporan yang dihasilkan yaitu laporan pasien dan laporan data rekam medis.
\end{abstract}

Kata Kunci : Sistem Informasi, Rekam Medis, Pasien. 


\section{PENDAHULUAN}

Penggunaan komputer sebagai salah satu sarana penunjang dalam sistem informasi dapat memberikan hasil yang lebih untuk output sebuah sistem, tentunya bila sistem didalamnya telah berjalan dengan baik (Ekowati, 2003). Rumah sakit sebagai salah satu institusi pelayanan umum membutuhkan keberadaan suatu sistem informasi yang akurat dan handal, serta cukup memadai untuk peningkatkan pelayanannya kepada para pasien serta lingkungan yang terkait lainnya. Dengan lingkup pelayanan yang begitu luas, tentunya banyak sekali permasalahan kom-pleks yang terjadi dalam proses pelayanan di rumah sakit. Banyaknya variabel di rumah sakit turut menentukan kecepatan arus informasi yang dibutuhkan oleh pengguna dan lingkungan rumah sakit. Pengelolaan data di rumah sakit merupakan salah satu komponen yang penting dalam mewujudkan suatu sistem informasi di rumah sakit.

Ada berbagai macam cara pencatatan rekam medis, salah satunya adalah cara tradisional yang mencatat manual dalam form yang berbentuk lembaran kertas. Cara ini mempunyai kelebihan dan kekurangan. Kelebihannya adalah data lebih fleksibel dan atau mudah untuk menyimpan berkas. Kekurangannya yaitu: membutuhkan waktu yang tidak sedikit untuk mencari data pasien dan rekam medis dapat dilakukan oleh siapapun, jadi keamanan maupun keaslian data dapat dipertanyakan kebenarannya.

Cara lainnya dalam mencatat manual yaitu terkomputerisasi, penyimpanan rekam medis yang digunakan bukan dalam bentuk lembaran kertas melainkan dalam komputer. Kelebihannya adalah lebih mudah dalam mencari informasi mengenai pasien, tidak membutuhkan ruang yang besar dalam penyimpanannya, lebih simple, meminima-lisir redudansi / rangkap data dan mudah diolah.

Kekurangannya adalah jika komputer rusak atau hilang maka data dapat diprediksi hilang semua, bersifat tidak fleksibel karena mengacu pada satu sistem yang dibuat. Kelengkapan pengisian berkas rekam medis oleh tenaga kesehatan akan memudahkan tenaga kesehatan lain dalam memberikan tindakan atau terapi kepada pasien.

Selain itu juga sebagai sumber data pada bagian rekam medis dalam pengolahan data yang kemudian akan menjadi informasi yang berguna bagi pihak manajemen dalam menentukan langkah-langkah strategis untuk pengembangan pelayanan kesehatan. Melihat situasi tersebut, penggunaan komputer dalam upaya membantu penanganan manajemen yang sebelumnya dilakukan secara manual menjadi terkomputerisasi, menjadi kebutuhan vital bagi rumah sakit.

Alat bantu yang dapat mendukung adalah dengan menggunakan program komputer, yang salah satunya yaitu dengan menggunakan program Sistem Operasi Windows minimal Windows XP khususnya sistem pengelolaan rekam medis di Rumah Sakit Bersalin Kertayasa yang di Bulan Oktober nanti akan menjadi Rumah Sakit Umum Kertayasa.Untuk itu penelitian dengan judul "Rancang Bangun Sistem Informasi Rekam Medis Berbasis Komputer" ini dilakukan agar dapat langsung diterapkan pada Rumah Sakit Bersalin Kertayasa.

\section{LANDASAN TEORI}

\section{Pengertian Rekam Medis}

Rekam medis adalah berkas yang berisi tentang catatan dan dokumen tentang identitas pasien, pemeriksaan, pengobatan, tindakan dan pelayanan lain kepada pasien di sarana pelayanan kesehatan (SK MenPAN No. 135/2002).

Rekam medis adalah fakta yang berkaitan dengan keadaan pasien, riwayat penyakit dan pengobatan masa lalu serta saat ini yang tertulis oleh profesi kesehataan yang memberikan pelayanan kepada pasien tersebut. (Health Information Management, Edna K Huffman, 1999).

Kegunaan rekam medis menurut Dirjen Pelayanan Medis Departemen Kesehatan Republik Indonesia No. 78/1991, yaitu: 1) Sumber informasi dari pasien yang berobat ke rumah sakit untuk keperluan pengobatan dan pemeliharaan kesehatan pasien. 2) Alat komunikasi antar dokter satu dengan dokter lain, antara dokter dengan paramedis dalam usaha memberikan pelayanan pengobatan dan perawatan. 3) Bukti tertulis tentang pelayanan yang telah diberikan rumah sakit dan keperluan lain. 4) Alat untuk analisis, penelitian dan evaluasi terhadap kualitas pelayanan yang diberikan rumah sakit. 5) Alat bukti hukum yang dapat melindungi kepentingan hukum bagi pasien, dokumen tenaga kesehatan lainnya di rumah sakit. 6) Menyediakan data khusus untuk penelitian dan pendidikan. 7) Perencanaan dan pemanfaatan sumber daya. 8) Keperluan lain yang ada kaitannya dengan rekam medis. 
Kegunaan rekam medis menurut Gibony, 1991 yang disingkat ALFRED adalah:

1) Administration/ Administrasi. Data dan informasi yang dihasilkan rekam medis dapat digunakan manajemen untuk melaksanakan fungsinya guna pengelolaan berbagai sumber daya, karena isinya menyangkut tindakan berdasarkan wewenang dan tanggung jawab sebagai tenaga rekam medis dalam mencapai tujuan pelayanan kesehatan. 2) Legal/Hukum Sebagai alat bukti hukum yang dapat melindungi hukum terhadap pasien, provider kesehatan (dokter, perawat dan tenaga kesehatan lainnya) serta pengelola dan pemilik sarana pelayanan kesehatan. Rekam medis mempunyai nilai hukum karena isinya menyangkut masalah adanya jaminan kepastian hukum, atas dasar keadilan dalam usaha menegakkan hukum serta penyediaan barang bukti untuk menegakkan keadilan. 3) Financial / Keuangan. Setiap jasa yang diterima pasien bila dicatat dengan lengkap dan benar maka dapat digunakan untuk menghitung biaya yang harus dibayar pasien, selain itu jenis dan jumlah pelayanan kegiatan yang tercatat dalam formulir dapat digunakan untuk memprediksi pendapatan dan biaya sarana pelayanan kesehatan. 4) Research / Penelitian. Berbagai macam penyakit yang telah dicatat dalam dokumen rekam medis dapat dilakukan penelusuran guna kepentingan penelitian dan pengembangan ilmu pengetahuan di bidang kesehatan.5) Education/Pendidikan Dokumen rekam medis dapat digunakan untuk belajar dan mengembangkan ilmu bagi mahasiswa atau pendidik. Dalam dokumen rekam medis terkandung data atau informasi tentang perkembangan kronologis dan kegiatan pelayanan medis yang diberikan pada pasien, informasi tersebut dapat digunakan sebagai bahan atau referensi pengajaran di bidang profesi pemakai.6) Documentation / Dokumentasi Rekam medis sebagai dokumen karena memiliki sejarah medis seorang pasien dipakai sebagai bahan pertanggung jawaban dan laporan rumah sakit.

Pada dasarnya struktur rekam medis terdiri dari 2 bagian pokok yaitu pencatatan atau penangkap data dan pengolahan data. Ditinjau dari cara memperoleh data pasien dan mengolah data sampai memperoleh informasi yang dibutuhkan rumah sakit maka beberapa tempat di luar dan di dalam rekam medis yang berfungsi sebagai perangkat dan penghasil data rekam medis yaitu :

\section{Unit Rawat Jalan}

Arti rawat jalan adalah pasien yang me-nerima pelayanan kesehatan di rumah sakit tanpa dirawat di rumah sakit, atau terdaftar sebagai pasien rawat inap (Ray, 1996). Pengertian tempat pendaftaran rawat jalan Rumah Sakit adalah tempat untuk setiap pa-sien Rumah Sakit mendaftarkan diri dalam rangka pemeriksaan diri atas status kesehatannya. Tempat Pendaftaran Pasien Rawat Jalan (TPPRJ) merupakan bagian yang bertanggung jawab terhadap data dan informasi indentitas pasien rawat jalan (Ditjen Yanmedis Depkes RI, 2005).

\section{Unit Rawat Inap}

Rawat inap (opname) adalah istilah yang be-rarti proses perawatan pasien oleh tenaga kesehatan profesional akibat penyakit tertentu, dimana pasien diinapkan dalam ruangan di rumah sakit. Unit rawat inap bertanggung jawab terhadap data dan pelayanan medis pasien yang dirawat inap (Ditjen Yanmedis Depkes RI, 2005).

\section{Unit Gawat Darurat (UGD)}

Yang dimaksud dengan pelayanan gawat darurat (emergency care) adalah bagian dari pelayanan kedokteran yang dibutuhkan oleh penderita dalam waktu segera (immediately) untuk menyelamatkan kehidupannya (life saving).Unit kesehatan yang menyeleng-garakan pelayanan gawat darurat disebut dengan nama Unit Gawat Darurat (Emergency Unit). Tergantung dari kemampuan yang dimiliki, keberadaan Unit Gawat Darurat (UGD) tersebut dapat beraneka macam. Namun yang lazim ditemukan adalah yang tergabung dalam Rumah Sakit (Hospital Based Emergency Unit) (Azwar, 1996).

\section{Sistem Informasi Rumah Sakit}

Sistem informasi rumah sakit adalah suatu tatanan yang berurusan dengan pengumpulan data, pengelolaan data, penyajian informasi, analisa dan penyimpulan informasi serta penyampaian informasi yang dibutuhkan untuk kegiatan rumah sakit.

Unsur sistem informasi rumah sakit antara lain yaitu:(a) Tugas, menyiapkan informasi untuk kepentingan pelayanan rumah sakit.(b) Tujuan, sistem informasi itu sendiri, dan sub-sistemnya terdiri dari sub-sistem pengembangan dan operasional sistem.(c) Struktur hirarki, sistem rumah sakit sebagai sistemnya.(d) Komponen, terdiri dari input, proses, output, dan balikan kontrol. 
Sistem informasi rumah sakit terbagi atas 3 jenis yaitu antara lain : (a) Sistem informasi klinik, merupakan sistem informasi yang secara langsung untuk membantu pasien dalam hal pelayanan medis. Contohnya yaitu: sistem informasi di $I C U$ dan sistem informasi pada alat penunjang diagnostik seperti $M R I$, $C T$ Scan dan $U S G$ tertentu. (b) Sistem informasi administratif, merupakan sistem informasi yang membantu pelaksanaan administrasi di rumah sakit. Contohnya: billing system, sistem informasi farmasi, dan sistem informasi penggajian. (c) Sistem informasi manajemen, merupakan sistem informasi yang membantu manajemen rumah sakit dalam pengambilan keputusan. Contohnya: sistem informasi manajemen pelayanan, sistem informasi keuangan, dan sistem informasi pemasaran.

Sistem informasi rumah sakit banyak berperan dalam berbagai hal seperti, pengendalian mutu pelayanan medis, pengendalian mutu dan penilaian produktivitas, Analisa pemanfaatan perkiraan kebutuhan, perencanaan dan evaluasi program, menyederhanakan pelayanan, penelitian klinis.

\section{Sistem Basis Data}

Database (basis data) merupakan kumpulan data yang saling berhubungan dan diorganisasi sedemikan rupa sehingga memudahkan untuk mendapat dan memprosesnya menjadi sebuah informasi yang lebih bermanfaat.

Data dan informasi merupakan salah satu aset paling penting dalam sebuah organisasi, baik kecil maupun besar. Selain itu, munculnya database tentunya telah memberikan kontribusi yang besar dalam pengelolaan data (Wahana Komputer, 2008).

Basis data terdiri dari dua kata, yaitu basis dan data. Basis dapat diartikan sebagai tempat penyimpanan sedangkan data adalah representasi fakta dunia nyata yang mewakili suatu obyek yang direkam dalam bentuk angka, huruf, simbol, teks.

Prinsip utama basis data adalah untuk pengaturan data dan tujuan utamanya adalah kemudahan dan kecepatan dalam pengambilan kembali data. Basis data digunakan untuk menyimpan, memanipulasi dan mengambil data hampir semua tipe perusahaan termasuk bisnis, pendidikan, rumah sakit, pemerintahan dan perpustakaan.

Data Base Management Sistem atau DBMS adalah sistem penyimpanan dan pengambilan data yang mengijinkan beberapa aplikasi untuk mengakses data tersebut dalam sebuah sistem terpadu sehingga tidak terjadi data redudancy dan integritas data dapat dipertahankan.

\section{Sistem Informasi Rekam Medis Elektronik}

Secara umum ada dua jenis rekam medis, yaitu : rekam medis kartu dan rekam medis elektronik. Sesuai dengan perkembangan teknologi, maka diterapkan suatu bentuk rekam medis berbasis komputer (elektronik) untuk mengatasi kekurangan - kekurangan pada rekam medis kartu, diantaranya : sulit menemukan data dan frag-mentasi.

Sistem informasi rekam medis elektronik adalah sistem penyimpanan infor-masi secara elektronik mengenai status kesehatan serta pelayanan kesehatan, yang diperoleh pasien sepanjang hidupnya dan tersimpan sedemikian hingga dapat melayani berbagai pengguna rekam yang sah (Shortlife, 2001).

Dengan adanya penyimpanan berkas rekam medis yang terkomputerisasi ini, menjadikan rekam medis tersebut mudah dan cepat diolah menjadi informasi dalam bentuk laporan-laporan maupun statistik perkembangan pelayanan kesehatan maupun statistik penyakit.

\section{METODE PENELITIAN}

\section{Lokasi Penelitian}

Penelitian dilaksanakan di Unit Rekam Medis pada Rumah Sakit Bersalin Kertayasa, Jalan Ngurah Rai 143, Kalurahan Dauh Waru, Kecamatan Negara, Kabupaten Jembrana, Provinsi Bali.

\section{Analisa Sistem}

Analisa sistem merupakan penguraian dari suatu sistem yang telah serta hambatanhambatan yang terjadi sehingga dari hasil analisa sistem tersebut dapat dirancang suatu sistem yang diperlukan agar menghasilkan kebutuhan-kebutuhan yang diperlukan.

Analisis sistem digunakan untuk menganalisa sistem yang sedang berjalan sehingga dapat dipahami keadaan sistem yang ada. Analisis sistem ini biasanya menggunakan diagram alir dokumen. Aliran dokumen dari bagian yang satu ke bagian yang lain dapat terlihat dengan jelas, begitu adanya penyimpanan data yang dilakukan secara manual.

Hasil daripada analisis sistem ini kemudian digunakan untuk merancang sistem informasi yang diperlukan. 


\section{Kerangka Berpikir}

Untuk dapat melakukan Perancangan Sistem Informasi Rekam Medis Bebasis Komputer di RSU Kertayasa Negara dilakukan analisa dan kajian yang tahapannya dijabarkan sebagai berikut :

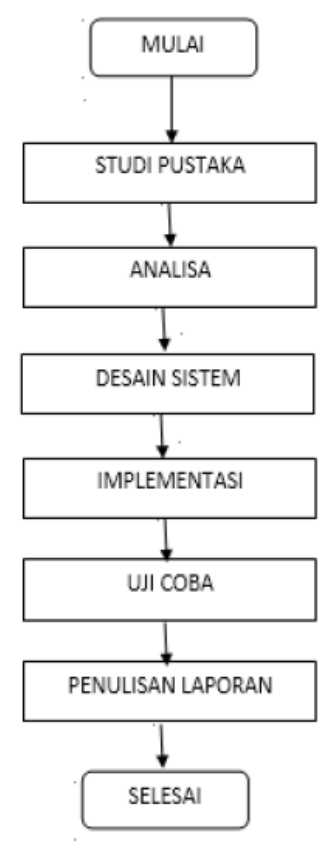

\section{Gambar 1 Kerangka Berpikir}

\section{Desain Sistem}

Tahap ini menyangkut mengkonfigurasi dari komponen-komponen perangkat lunak (software) dan perangkat keras (hardware) dari suatu system sehingga setelah instalasi dari sistem akan benar-benar menghasilkan hasil yang diinginkan. Komponen desain sistem dalam merancang dan membuat sistem informasi rumah sakit online ini antara lain; Rancangan DFD (Data Flow Diagram), ERD (Entity Relationship Diagram), Konseptual Database, dan Desain Interface.

\section{HASIL DAN PEMBAHASAN}

\section{Spesifikasi Sistem}

Dalam pembuatan Sistem Informasi Rekam Medis RSU Kertayasa dibutuhkan perangkat lunak dan perangkat keras sebagi berikut :

\section{Perangkat Lunak}

Perangkat Lunak yang dibutuhkan untuk Sistem Informasi Rekam Medis RSU Kertayasa adalah : Sistem Operasi Windows minimal windows XP atau Ubuntu; Database MySql; Webserver.

\section{Perangkat Keras}

Perangkat keras yang dibutuhkan untuk Sistem Informasi Rekam Medis RSU Kertayasa adalah Procesor Pentium IV, Memori 512 MB, Hardisk 250 GB, Monitor, Mouse dan Keyboard.

\section{Perancangan Sistem}

Perancangan sistem sangat diperlukan dalam pembuatan sistem agar dalam pengembangannya menjadi terarah dengan baik. Perancangan sistem juga bertujuan untuk merencanakan tahapan, alur dan struktur sistem yang akan dibuat. Perancangan proses pada sistem akan dijelaskan menggunakan flowchart, proses proses yang ada pada sistem adalah sebagai berikut :

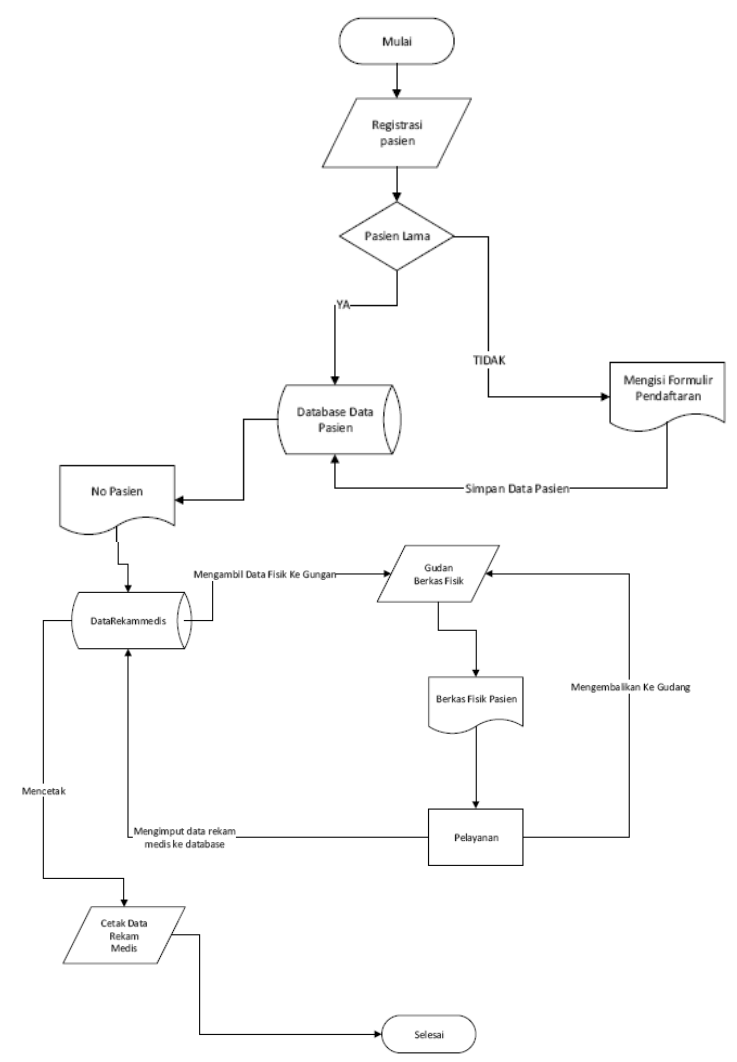

\section{Gambar 2 Perancangan proses}

\section{Perancangan Form}

Sistem Informasi Rekam Medis RSU Kertayasa terdiri dari beberapa form, form form yang akan dirancang adalah sebagai berikut: 


\section{Form Login}

Form Login adalah form yang akan pertama kali muncul saat sistem di akses, tampilan form login seperti berikut:

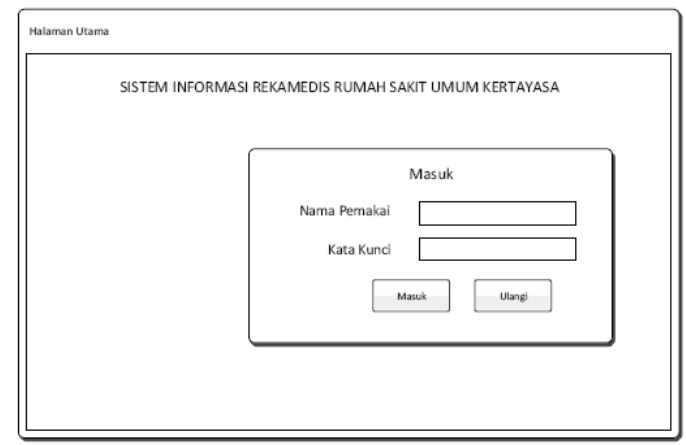

Gambar 3 Form Login

\section{Form Utama}

Form utama adalah form yang akan muncul setelah pemakai melakukan login, tampilan form utama adalah sebagai berikut:

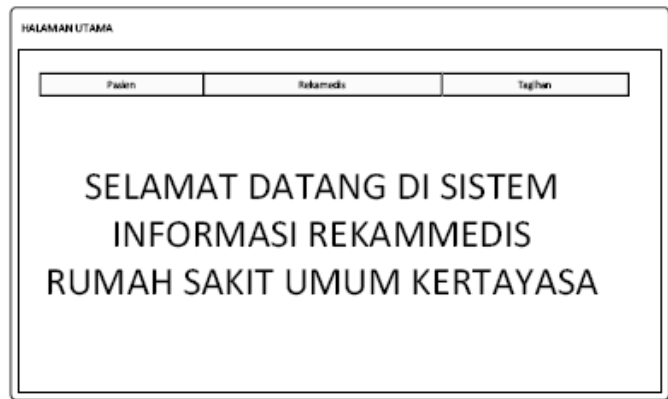

Gambar 4 Form Utama

\section{Form Pendaftaran Pasien}

Form pendaftaran pasien adalah form yang digunakan untuk melakukan pendaftaran pasien pertama kali. Tampilan form pendaf-taran pasien adalah sebagai berikut:

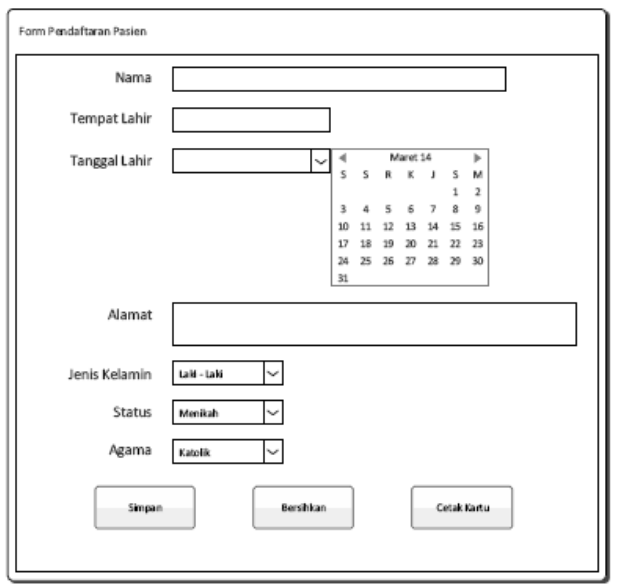

Gambar 5 Form Pendaftaran Pasien

\section{Form Rekam Medis}

Form Rekam Medis merupakan form untuk menginputkan perawatan yang telah di dapat pasien, form Rekam Medis adalah sebagai berikut:

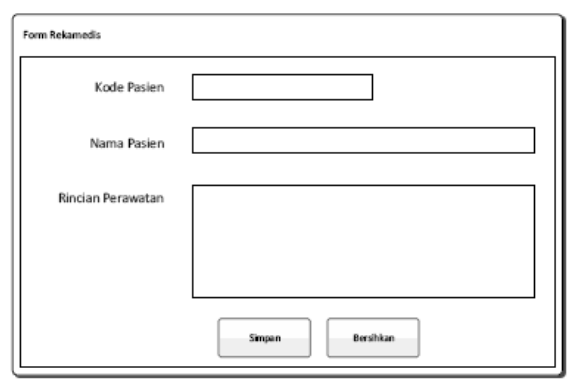

Gambar 6 Form Rekam Medis

Perancangan Output Data Pemeriksaan

Sistem Informasi Rekam Medis RSU Kertayasa akan mengeluarkan output berupa data permeriksaan pasien, Peranca-ngan data pemeriksaan pasien adalah se-bagai berikut :

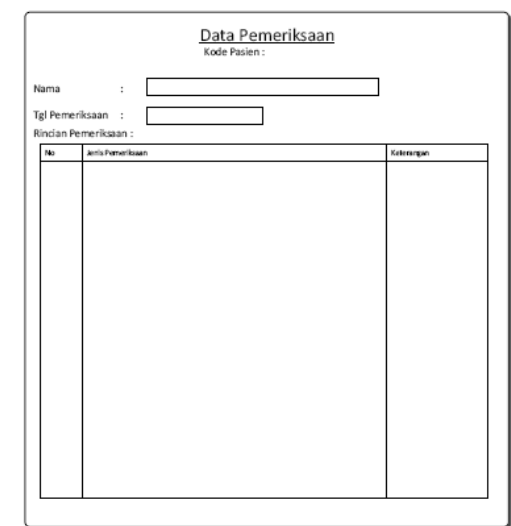

Gambar 7 Perancangan Output Data Pemeriksaan

\section{Perancangan Database}

Perancangan Database yang akan digunakan oleh Sistem Informasi Rekam Medis RSU Kertayasa adalah sebagai berikut:

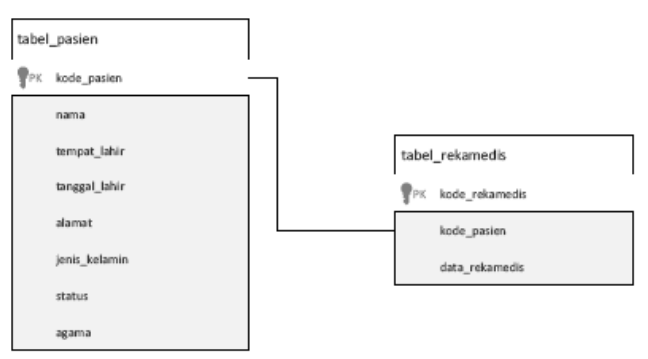

Gambar 8 Perancangan Database 
Database rekam medis akan memilis 2 buah tabel, yaitu Tabel Pasien dan Tabel Rekam Medis

\section{Implementasi Sistem}

Implementasi dari perancangan sistem rekam medis adalah sebagai berikut: Sistem Informasi Rekam Medis RSU Kertayasa Negara memiliki beberapa bagian yaitu Halaman Sistem Utama, Admin Sistem, Pendaftaran dan Bagian Administrasi.

\section{Halaman Utama Sistem}

Halaman utama sistem merupakan halaman yang muncul pertama kali ketika mengakses sistem informasi, halaman utama dari sistem ditampilkan seperti gambar berikut :

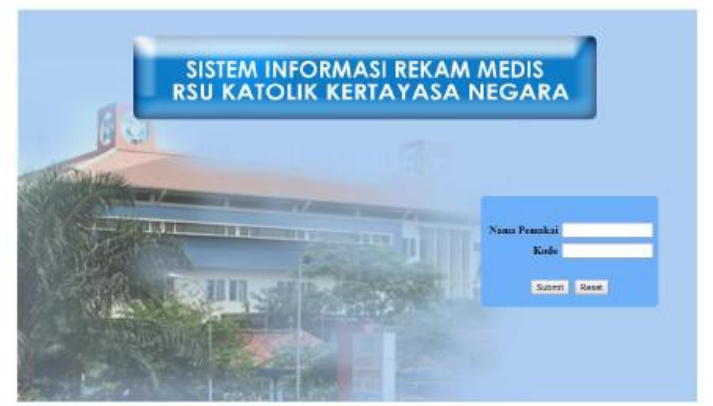

Gambar 9 Halaman Utama Sistem

Pada halaman utama sistem akan muncul form login untuk menentukan user yang mengakses pada sistem, form login seperti berikut:

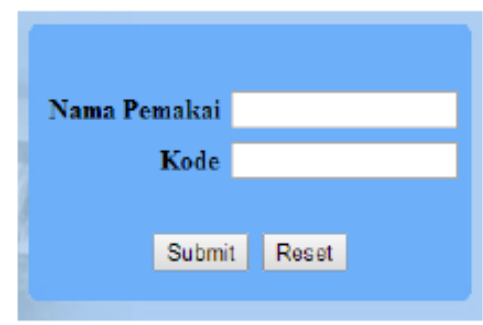

\section{Gambar 10 Form Login}

Pada form login tersebut kita memasukkan nama pemakai dan kode pemakai ada tiga kategori user yang dapat masuk ke dalam sistem. (1) Admin Sistem yaitu user yang dapat melihat semua aktivitas dari sistem, admin sistem dalam melakukan semua kegiatan yang dilakukan oleh user pendaftaran dan user administasi. (2) User Pendaftaran adalah user yang dapat melakukan aktivitas pendaftaran pasien.
(3) User administrasi adalah user yang dapat mencatat aktivitas rekam medis pasien dan membuat tagihan layanan yang diberikan kepada pasien.

\section{Halaman Utama Pendaftaran}

Halaman utama pendaftaran adalah halaman yang digunakan oleh user pendaftaran, halaman utama user pendaftaran adalah seperti berikut.

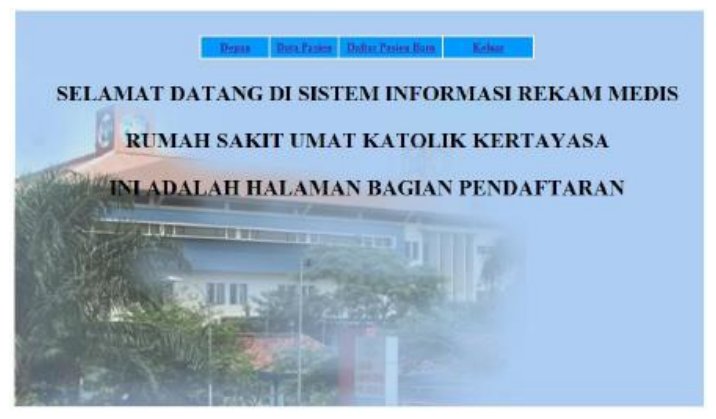

\section{Gambar 11 Halaman Utama Bagian Pendaftaran}

Pada halaman utama pendaftaran ditampilkan link ke halaman yang dapat diakses oleh user pendaftaran. Halaman yang digunakan untuk mendaftarkan pasien baru adalah sebagai berikut:

\section{Form Untuk Daftar Pasien}

Form untuk Daftar Pasien adalah form yang digunakan untuk pendaftaran pasien baru, form pendaftaran ditampilkan seperti gambar berikut:

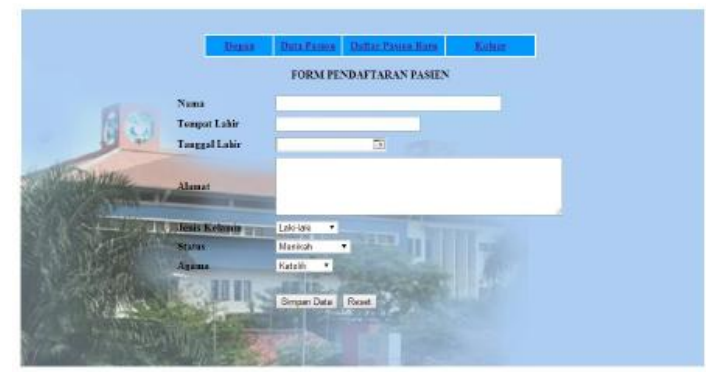

\section{Gambar 12 Form Pendaftaran Pasien}

Pada form pendaftaran data yang harus diisi adalah : Nama, Tempat Lahir, Tanggal Lahir, Alamat, Jenis Kelamin, Status, Agama.

Semua data harus diisi untuk memudahkan dalam merincikan setiap pasien. Setelah semua data diisi maka selanjutnya data tersebut disimpan di database pasien. 


\section{Halaman Utama Administrasi}

Halaman Utama Administrasi adalah halaman yang digunakan oleh user administrasi, halaman utama administrasi menampilkan link ke halaman lain yang terkait dengan user administrasi.

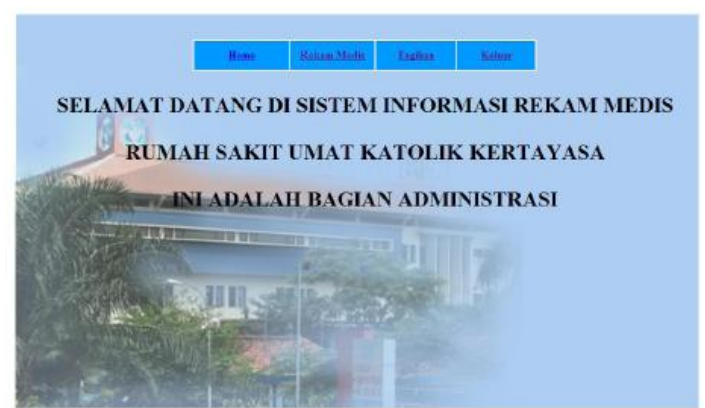

Gambar 13 Halaman Utama Administrasi

\section{Form Rekam Medis}

Form Rekam Medis adalah form yang digunakan untuk mencatat Rekam Medis dari setiap pasien. Pada form rekam medis data yang harus diisi adalah : Kode Pasien, Nama Pasien, Rincian Rekam Medis.

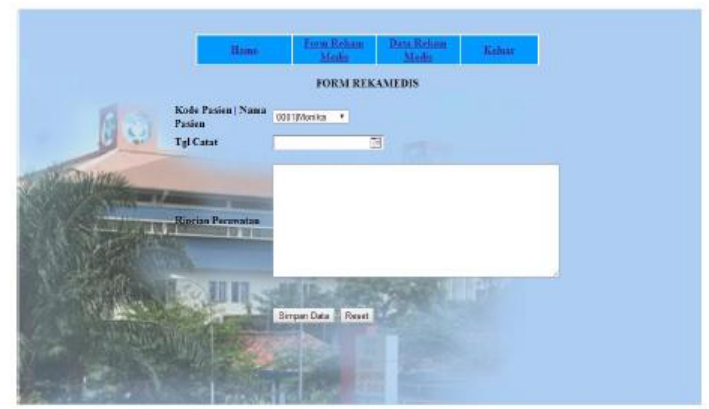

Gambar 14 Form Rekam Medis

\section{Form Laporan}

Sistem informasi Rekam Medis RSU Kertayasa dapat menampilkan laporan pasien dan laporan data rekam medis.

\section{Laporan Pasien}

Pada laporan pasien, informasi yang diberikan adalah : Nomor Pasien; Nama $\mathrm{Pa}$ sien; Alamat Pasien. Laporan data pasien ditampilkan seperti berikut :

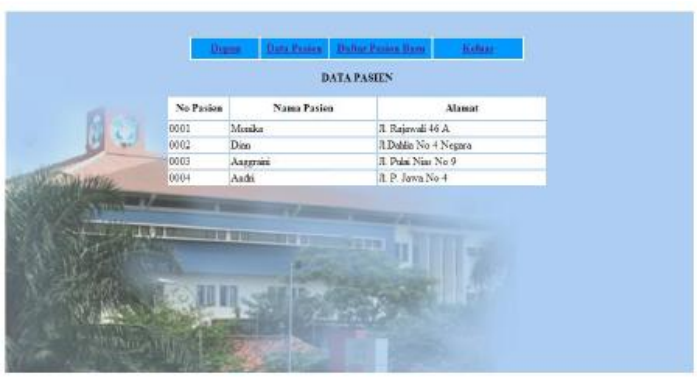

Gambar 15 Form Laporan Data Pasien

\section{Laporan Data Rekam Medis}

Laporan data rekam medis menampilkan informasi data rekam medis dari pasien, data yang ditampilkan adalah sebagai berikut : Kode Pasien; Nama Pasien; Alamat Pasien; Tanggal Periksa; Rincian Pemeriksaan; Kode Penyakit (ICD-10)

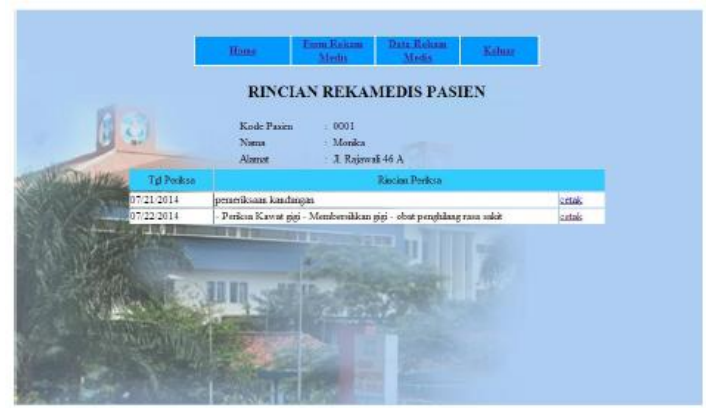

\section{Gambar 16 Laporan Data Rekam} Medis

Hasil cetak data rekam medis pasien adalah sebagai berikut:

\section{RINCIAN REKAMEDIS PASIEN}

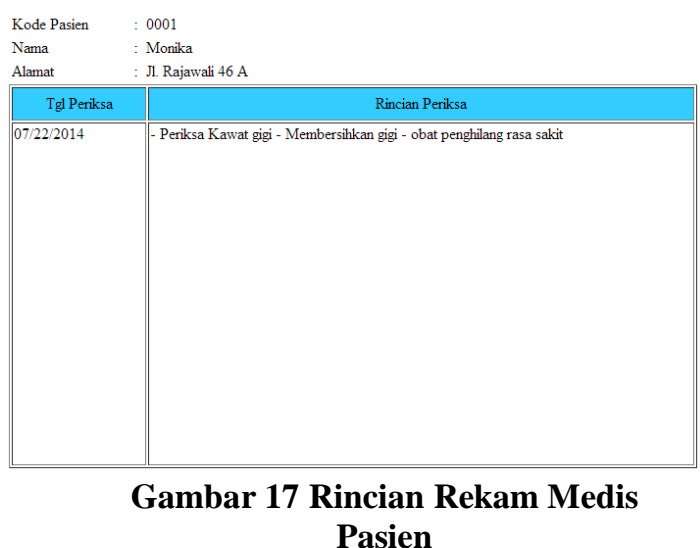




\section{SIMPULAN}

Dari hasil Analisis terhadap Sistem Informasi Rekam Medis Berbasis Komputer yang akan diterapkan di RSB Kertayasa Negara, maka dapat ditarik beberapa kesimpulan sebagai berikut; Sistem Informasi Rekam Medis Berbasis Komputer dapat membantu melakukan dokumentasi secara digital terhadap data rekam medis pasien. Dengan menggunakan Sistem Informasi Rekam Medis berbasis Komputer dapat memasukkan data rekam medis pasien lebih mudah dan cepat. Pencarian data rekam medis pasien lebih mudah dan cepat dengan menggunakan Sis-tem Informasi Rekam Medis Berbasis Kom-puter. Penyimpanan data rekam medis lebih ringkas dan terstruktur dengan baik.

\section{DAFTAR PUSTAKA}

[1] Aditama T. Y, 2006. Manajemen Administrasi Rumah Sakit. Edisi Kedua, Jakarta: Universitas Indonesia.

[2] Astaqauliyah, 2008. Pengertian dan Fungsi Rumah Sakit. (tersedia) http://astaqauliyah.com/2008/01/01/pen gertian-dan-fungsi-rumah-sakit/ [diunduh tanggal 5 Juni 2014].

[3] Azwar A, 1996. Pengantar Administrasi Kesehatan. Edisi Ketiga, Jakarta: Binarupa Aksara.

[4] Direktorat Jendral Pelayanan Medik. (1997) Pedoman Penyelenggaraan Rekam Medis Rumah Sakit di Indonesia. Jakarta: Departemen Kesehatan RI.

[5] Direktorat Jendral Pelayanan Medik. (2005) Buku Petunjuk Pengisian Pengolahan dan Penyajian Data Rumah Sakit. Jakarta : Departemen Kesehatan RI.

[6] Eko R, 2000. Manajemen Sistem Informasi dan Teknologi Informasi. Jakarta: PT Elex Media Komputindo.

[7] Ekowati Y, 2003. Rancangan Basis Data Informasi Morbiditas Yang Berbasis Komputer Di Balai Pengobatan Umum (BPU) Puskesmas Petarukan Kecamatan Petarukan Kabupaten Pemalang. Skripsi Fakultas Kesehatan Masyarakat Universitas Diponogoro. Semarang. (tersedia) http://sia.fkm-undip.or.id/ [diunduh tanggal 09 Juni 2014].

[8] Ery Rustiyanto, 2010. Sistem Informasi Manajemen Rumah Sakit Yang Terintegrasi. Edisi Pertama, Yogyakarta : Penerbit Gosyen Publishing.
[9] Gemala Hatta, 2010. Pedoman Manajemen Informasi Kesehatan di Sarana Pelayanan Kesehatan. Edisi Revisi, Jakarta : Penerbit Universitas Indonesia.

[10] Harianto Kristanto, 1994. Konsep dan Perancangan Database.Yogyakarta: Andi Offset.

[11] Jogiyanto H. M, 2005. Sistem Teknologi Informasi . Yogyakarta: Andi Offset.

[12] Keputusan Menteri Kesehatan Republik Indonesia No. 159b/MENKES/PER/II/1988. Rumah Sakit . Jakarta: DepKes RI. [diunduh tanggal 10 Mei 2014]

[13] Keputusan Menteri Kesehatan Republik Indonesia No.

269/MENKES/PER/III/2008 tentang Rekam Medis . Jakarta: DepKes RI. [diunduh tanggal 2 Juni 2014]

[14] Lidya Andriani, 2009. Sistem Informasi Pendaftaran Pasien Rawat Jalan di Rumah Sakit Dengan Menggunakan Program Komputer, 2009. Skripsi Fakultas Kesehatan Masyarakat. Universitas Sumatera Utara. (tersedia) http://female.store.co.id/images/ media/skripsi. [diunduh 10 Juni 2014].

[15] Muninjaya A. A, 2004. Manajemen Kesehatan. Jakarta: EGC.

[16] Sanjoyo R, 2007. Sistem Informasi Kesehatan. ) http://yoyoke.web.ugm.ac.id/ download/ sik dan sirs.pdf/. [diunduh tanggal 10 Juni 2014].

[17] Sutanta E, 2003. Sistem Informasi Manajemen. Edisi Pertama, Yogyakarta: Graha Ilmu.

[18] Sutedjo B, 2002. Perencanaan dan Pembangunan Sistem Informasi. Yogyakarta: Andi Offset.

[19] Wahyu W, 2004. Sistem Informasi Manajemen.Yogyakarta: UPP (Unit Penerbit dan Percetakan) AMP YKPN.

[20] Wikipedia, 2008. Rumah Sakit. (tersedia) http://id.wikipedia.org/wiki/Rumah_saki t/ [diunduh tanggal 6 Desember 2008].

[21] Yung K, 2004. Membangun Database dengan Visual Basic 6.0 dan Perintah $S Q L$. Jakarta: PT Elex Media Komputindo.

[22] Zeni Kurnia. Sistem Informasi Rekam Medis. (tersedia) http://perekam_medis. blogspot.com [diunduh tanggal 24 Maret 2014]. 